EDUCATIONAL

RESOURCE

Volume 13 Issue 22021

DOI: 10.21315/eimj2021.13.2.10

ARTICLE INFO

Received: 23-09-2020

Accepted: 02-03-2021

Online: 30-06-2021

\title{
A Case of Incest in a Malaysian Child: The Ethical and Legal Implications
}

\author{
Nur Jannah Abdul Ghani', Siti Aqilah Muhamad', Nur'amahirah \\ Hasan Zaki' ${ }^{1}$, Mohd Assyakir Shamsuddin', Fahisham Taib ${ }^{1,2}$ \\ ${ }^{1}$ Hospital Universiti Sains Malaysia, Kelantan, MALAYSIA \\ ${ }^{2}$ School of Medical Sciences, Universiti Sains Malaysia, \\ Kelantan, MALAYSIA
}

To cite this article: Abdul Ghani NJ, Muhamad SA, Hasan Zaki N, Shamsuddin MA, Taib F. A case of incest in a Malaysian child: the ethical and legal implications. Education in Medicine Journal. 2021;13(2):101-105. https://doi.org/10.21315/eimj2021.13.2.10

To link to this article: https://doi.org/10.21315/eimj2021.13.2.10

\section{ABSTRACT}

Serious crimes, especially child sexual abuse and rape have become one of the most unsettling issues all over the world. Survivors of these ordeals are facing and suffering from traumatic life experiences. We illustrated a case of a 13-year-old girl who was involved in an incestuous relationship and the challenges from the ethical perspective of a professional. It is essential that healthcare professionals be equipped with awareness on the legal impact of such case - related to child protection policy, child rehabilitation process and the penal code related to such event.

Keywords: Incest, Child abuse, Statutory rape, Child maltreatment, Child protection

Fahisham Taib, School of Medical Sciences, Universiti Sains Malaysia, 16150 Kubang Kerian, Kelantan, Malaysia

Email: fahisham@gmail.com

\section{INTRODUCTION}

Rape is an unlawful sexual intercourse between a man and a woman without the latter's consent and against her will (1). It is classified into statutory, non-statutory and incestuous. According to Penal Code, Section $375(\mathrm{~g})$, statutory rape is defined as unlawful sexual intercourse between man and woman under the age of 16 , regardless of their consent (1).

In one-third of the countries across the world, at least $5 \%$ of young women are reported to have experienced some form of sexual violence during their childhood (2). The victims for incest cases are from the age of 13 to 15 years old, and thus considered as statutory rape (3). Documented rape cases vary from 1,163 to 1,760 cases (2013 to 2017), and majority occurred to women below 18 years old (4). Generally, punishment for child sexual abuse is imprisonment for a term which may extend to 30 years and shall also be liable to whipping (1).

\section{CASE}

$A$, a 13 years 11 months old schoolgirl, presented to tertiary hospital with symptoms of active labour. Initially, she refused to reveal the offender but after a few consultations, she revealed that she was raped by her brother, aged 15, twice at home. She did not display any enragement towards her brother for violating her 
honour. Both are very close siblings and have mutual feeling for each other. She also did not show any depressive symptoms after the incident. $A$ came from a family with low socioeconomic background. Her father suffered from stroke, leaving her mother as the sole breadwinner for the family. She has seven siblings. Her mother was emotionally traumatised when $A$ disclosed the event. Mother was having conflicting feelings between guilt, shame and wanting to protect the family, hence, her disagreement to lodge a police report. $A$ had an uncomplicated delivery of a baby girl but the baby developed a metabolic crisis and died shortly afterwards. $A$ was discharged home following her brother's imprisonment behind the bar.

\section{ETHICO-LEGAL DISCUSSION}

The case illustrates a few ethical challenges:

a. How do we respond professionally as a doctor, knowing the psychosocial dynamic in an incestuous relationship?

b. What is our position when the family decided against lodging a police report; giving reasons of family's shame and guilt for their inability to protect the victim or perpetrator?

c. How do we plan for the unborn child from this consummate incest episode?

In Malaysia, social acceptance of teenage pregnancy is still restricted and secluded. Premarital sex, either due to incest, statutory rape, sexual abuse, or teen marriage, is considered a socially taboo topic for discussion in Malaysian context (5). The majority of the reported cases of statutory rape, which contributed to teenage pregnancies, were girls from the urban poor with poverty-stricken background (9). They are at a greater risk of being involved in premature sexual activities and eventually out of wedlock pregnancy (6). These poor, unwed and underage mothers are not socially accepted by their own parents, further escalating the practice of illegal abortion, baby dumping or abandonment as an illegitimate child that would bring shame to the family. Malaysian society often stigmatises and stereotypes the victims with delinquency, practising free sex, substance abuse and raised from a dysfunctional family background (7). The culture of silence and social stigma within our communities has further worsened the situation and fear among the victims.

Statutory rape and teenage pregnancy have negatively impacted the young girls, medically, psychologically as well as her socioeconomic well-being. They are predisposed to domestic violence, physical abuse, loss of educations and future employment opportunities. Many of the victims quit schooling prematurely, leading to the inability to gain essential knowledge and life skills for their survival (8). Additionally, the social stigma and abandonment by the family have negatively alienated victims from the community and predisposed them to mental health (8). It is important that confidentiality of patients' information is kept private when dealing with such cases. This is part of the good faith that exists between doctors and patients. To answer Question A, it is professionally obligatory that the focus of care is to ensure the safety of the child, and the axis of our action should be geared towards protecting the victims from further abuse. There are situations where breaching of confidentiality would be necessary especially when the benefits of breaching the information outweigh the harms to the victims. This is true when a child is at risk of or suffering from maltreatment. The cases involving young offenders usually occurred due to their curiosity to explore the pleasures of the body and naivety of experience without thinking of the future repercussion of their action. These children should be given treatment based on the ethical concept of beneficence and according to the hospital standard without potentially mitigating mistrust relationship between the managing team and the parents. 
The lack of effective intervention support system often leaves the affected parents believing that underage marriage is the best solution when their children become sexually active or become pregnant. In Malaysia, child marriage has been an option to save the baby from illegitimacy and to protect their daughters from the dishonour position due to rape (9). The age of consent in Malaysia is 16 years old, in which an individual is considered legally able to give consent to sexual activity and the rationale for imposing a certain age limit is to protect and regulate on the young people's sexual behaviour. However, several legal policies have hindered the effort to curb this issue. For instance, our civil law stipulates that 18 years old is the legal age for non-Muslim marriage and the Muslim law allows Muslim girl to get married at 16 years old and boys at 18 years old. The Syariah Court may grant permission to marry below those fragile age where the level of their maturity is debatable (1). The friction opinion between different existing laws in Malaysia may worsen the situation and the establishment of a clear minimum age for marriage is therefore the key first step to halt statutory rape which often lead to teen marriage in Malaysia.

Parents may opt to force legal child marriage or not reporting a "statutory rape". In the legal framework, not reporting a statutory rape is considered as an offence. The Child Act 2001 stated that cases of incest and statutory rape could be charged and punishable under Penal Code, Section $376(1)$. It is vital that police report is made to allow the police or child protector to work within the boundary of the law and to protect the minors. Crisis such as forced marriage requires a planned intervention towards the safety and protection of a vulnerable child and working collaboratively within the dynamic of the family. Child abuse is considered as social emergency; healthcare professionals should act swiftly to ensure children's rights are uphold and this would be a vital step to avoid unwanted consequences. In the context of incest, often the children are forced to be silent and comply with the family's demand. There is a huge psychological barrier to disclose because the family's name could be tarnished. The act of silence may lead to the continuous immoral activities. With incest, as the perpetrator is related to the victim, disclosure by the victim is more problematic as the victim is consumed with humiliation. Many of these cases went unresolved due to under reported. Child friendly reporting measure is vital to remove social stigma and protect the victims. This is an important action as professional, despite family disagreement as posed in Question B.

Despite of the mentioned hurdle on the Malaysian legal systems, the definition of "child" in the context of child marriage age limit has been an unresolved challenge for the government to reinforce the law and to deter underage marriage. The recent laws need reformation and harmonisation with the Syariah Law to protect the teenagers and to punish the offender accordingly. Educating the public is equally important. The existing laws and punishments need to be publicised to dissuade others from doing the act. The public also need to be informed about the danger of the incestuous relationship, physiologically and socially such as the risk of having disabled child. The incestuous relationship is a condemn act in every religion, country and lifeprinciple, and could lead to stigma and social isolation.

There are also challenges in managing the aftermath of the event. A baby who is born from an incestuous relationship is deemed to have medical issues due to close sibship and consanguinity. The complexity of the baby's medical needs would require the caregivers to be competent and capable of looking after the baby. This will be an enormous task for a young mother and even overwhelming the grandparent financially, medically and socially. The cost of managing complex medical issues are colossal and the ability of the family will be under scrutiny. Safety of the baby will also be paramount for his 
or her future care and support. If the baby survives (as per Question C), evaluation for adoption would be a necessary step if the family is unwilling to care for the unfortunate baby. This should be discussed between the managing agencies within the One Stop Crisis Centre (OSCC) multidisciplinary team.

The OSCC is an integrated multi-agency service with a comprehensive approach consisting of medical, psychological, social, shelter and legal support to help the victims of violence and readily available in every hospital (10). It is important for the OSCC team to function professionally and provide a strong support system to the victim. This includes shelter homes for unwed teenage mother for various reasons, adoption centers, childcare services, financial incentives as well as emotional support (7). There is also the taboo on discussing sexuality in Malaysia, and is considered as an inappropriate topic, governed by perception of religion teaching (11). Without sex education, the focus on sexual behaviour, reproduction health, sexual attitude, sexual health care and relationship within the cultural, moral and religion values could not be discussed among the adolescent.

\section{CONCLUSION}

Statutory rape and teenage pregnancy cases have been on the rise in our country. Issues of stigma, discrimination, denial and ignorance continue to have an impact on every child sexual abuse case in Malaysia. Professionally, we should ethically act according to the standard requirement without abandoning them despite the emergency nature of the condition. Malaysia faces uphill challenge in addressing this due to the social and cultural understanding of the issue.

\section{REFERENCES}

1. Abdullah NA, Haneef SSS. The statutory rape law in Malaysia: an analysis from shariah perspective. International Journal of Business, Economics and Law. 2017;14(5):9-14.

2. UNICEF [Internet]. New York: UNICEF; 2020 June [cited 2020 Sept 20]. Sexual violence in childhood. Available from: https://Data.Unicef.Org/Topic/ChildProtection/Violence/Sexual-Violence/

3. The Woman's Aid Organization [Internet]. Petaling Jaya, Malaysia: WAO; c2020 [cited 2020 Sept 20]. Incest statistics. Available from: https://wao.org.my/Incest-Statistics/

4. The Woman's Aid Organization [Internet]. Petaling Jaya, Malaysia: WAO; c2020 [cited 2020 Sept 20]. Rape statistics. Available from: https://wao.org.my/Rape-Statistics/

5. Tan SMK, Mohamed Saini S, Lee VY, Wahab S, Chan LF, Mohd Ijam SH, Nor NK. Child protection issues: incest-the Malaysian scenario. Adolescent Psychiatry. 2014;4(4):225-32. https://doi.org/10.2174/2 21067660404150115160153

6. Young T, Turner J, Denny G, Young M. Examining external and internal poverty as antecedents of teen pregnancy. Am J Health Behav. 2004;28(4):361-73. https://doi.org/ 10.5993/AJHB.28.4.8

7. Saim NJ. Social support, coping, resilience and mental health in Malaysian unwed young pregnant women and young mothers: their experiences while living in a shelter home. PhD diss., Umea University, Sweden; 2013.

8. Saim NJ, Dufaker $M$, Ghazinour $M$. Teenagers' experiences of pregnancy and the parents' and partners' reactions: a Malaysian perspective. J Fam Viol. 2014;29:465-72. https://doi.org/10.1007/s10896-014-9595-4 
9. Mohd Awal NA, Samuri MAA. Child marriage in Malaysia (working paper). Malaysia: UNICEF; 2018 [cited 2020 Sept 20]. Available from: https://www.unicef. org/malaysia/media/711/file/Child $\% 20$ marriage $\% 20$ in $\% 20$ Malaysia.pdf

10. Ministry of Health Malaysia. One Stop Crisis Center: policy and guidelines for hospitals. Putrajaya: Ministry of Health Malaysia; 2015.
11. Ahmad A, Ramzi Sulaiman NFA. Consensual incest: the legal environment in Malaysia. International Journal for Studies on Children, Women, Elderly and Disabled. 2017;1:9-15. 